Universidad de Lima

Facultad de Derecho

Carrera de Derecho

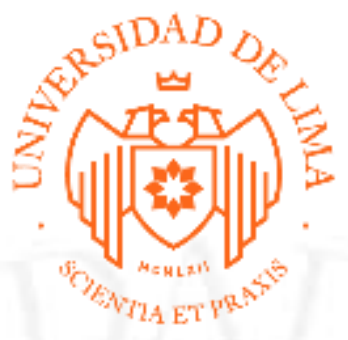

\title{
CIVIL: "INDEMNIZACIÓN POR DAÑOS Y PERJUICIOS" Y ADMINISTRATIVO: "PROTECCIÓN AL CONSUMIDOR"
}

Trabajo de suficiencia profesional para optar el Título Profesional de Abogado

\author{
Samuel Eduardo Córdova Marroquin
}

Código 20110343

Lima - Perú

Agosto de 2019 


\section{CIVIL: "INDEMNIZACIÓN POR DAÑOS Y PERJUICIOS"}

Materia: Responsabilidad Civil Indemnización por daños y perjuicios

$\mathrm{N}^{\mathrm{o}}$ de Expediente: 082-2003

\section{RESUMEN}

En el presente caso, se interpone una demanda por indemnización de daños y perjuicios derivados de una sentencia de divorcio por la causal de separación de hecho, obtenida por el demandado, de acuerdo a lo establecido en el artículo 345-A del Código Civil.

\section{ADMINISTRATIVO: "PROTECCIÓN AL CONSUMIDOR"}

Materia: Protección al Consumidor

No de Expediente: 2573-2012/CPC

\section{RESUMEN}

El expediente consiste en una denuncia interpuesta por un consumidor en contra de una empresa perteneciente al rubro de construcción, en este caso en particular se denunció la infracción del deber de idoneidad establecido en el artículo 18 del Código de Protección y Defensa del Consumidor. 